\title{
Progesterone and interferon tau regulate leukemia inhibitory factor receptor and IL6ST in the ovine uterus during early pregnancy
}

\author{
Gwonhwa Song, M Carey Satterfield, Jinyoung Kim, Fuller W Bazer and Thomas E Spencer \\ Department of Animal Science, Center for Animal Biotechnology and Genomics, Texas A\&M University, \\ 442 Kleberg Center, 2471 TAMU, College Station, Texas 77843-2471, USA \\ Correspondence should be addressed to TE Spencer; Email: tspencer@tamu.edu \\ G Song, M C Satterfield and J Kim contributed equally to this study and should be considered co-first authors
}

\begin{abstract}
The actions of leukemia inhibitory factor (LIF) via LIF receptor (LIFR) and its co-receptor, IL6 signal transducer (IL6ST), are implicated in uterine receptivity to conceptus implantation in a number of species including sheep. The present study determined the effects of the estrous cycle, pregnancy, progesterone (P4), and interferon tau (IFNT) on the expression of LIFR and IL6ST in the ovine uterus. LIFR mRNA and protein were localized to the endometrial luminal (LE) and superficial glandular epithelia (sGE), whereas IL6ST mRNA and protein were localized primarily in the middle to deep GE. Both LIFR and IL6ST mRNAs and protein were more abundant in pregnant than cyclic ewes and increased from days 10 to 20 of pregnancy. Treatment of ovariectomized ewes with P4 and/or infusion of ovine IFNT increased LIFR and IL6ST in endometrial LE/sGE and GE respectively. Co-expression of LIFR and IL6ST as well as phosphorylated STAT3 was observed only in the upper GE of the endometrium as well as in the conceptus trophectoderm on days 18 and 20 . In mononuclear trophectoderm and GE cells, LIF elicited an increase in phosphorylated STAT3 and MAPK3/1 MAPK proteins. Collectively, these results suggest that LIFR and IL6ST are both stimulated by IFNT and regulated by P4 in a complex stage- and cell-specific manner, and support the hypothesis that LIF exerts effects on the endometrial GE as well as conceptus trophectoderm during early pregnancy in sheep. Thus, LIF and STAT3 may have biological roles in endometrial function and trophectoderm growth and differentiation.
\end{abstract}

Reproduction (2009) 137 553-565

\section{Introduction}

Leukemia inhibitory factor (LIF), a member of the interleukin 6 (IL6, also known as interferon beta 2 (IFNB2)) cytokine family, is a secreted glycoprotein that acts as a polyfunctional cytokine in a variety of tissues and cells types (see (Auernhammer \& Melmed 2000) for a review). LIF binds to the LIF receptor (LIFR) with low affinity and subsequently recruits IL6 signal transducer (IL6ST, also known as GP130) as a co-receptor. This heterodimer complex with high affinity for LIF activates janus kinase 1 or $2(J A K 1 / 2)$ and tyrosine kinase 2 (TYK2), and then signal transducer and activator of transcription (STAT), particularly STAT3, to regulate target gene expression (see (Shields et al. 1995, Auernhammer \& Melmed 2000) for a review). In addition to the JAK-STAT signaling pathway, LIF also activates the MAP kinase (MAPK), protein kinase C (PKC), and phosphatidylinositol 3-kinase (PI3K) pathways. In mice, Lif is expressed exclusively in endometrial GE and plays an essential role in blastocyst implantation via the effects on endometrial LE (Bhatt et al. 1991, Stewart et al. 1992). In the mouse uterus, Lifr and Il6st are co-expressed in the LE, and LIF activates LIFR and then STAT3 at the time of blastocyst attachment (Cheng et al. 2001, Song \& Lim 2006). In Lifr null mice, embryos attach to the endometrial LE successfully, but perinatal death occurs (Ware et al. 1995), whereas Il6st null embryos die in utero due to myocardial and hematological defects (Yoshida et al. 1996). In mice, LIF regulates the onset of uterine receptivity to blastocyst implantation and embryogenesis (see (Vogiagis \& Salamonsen 1999, Cheng et al. 2002, Kimber 2005) for a review). Of particular note is that LIF regulates trophoblast giant cell differentiation in the mouse placenta (Takahashi et al. 2008), and human extravillous trophoblast invasion is stimulated by both LIF and STAT3 (Poehlmann et al. 2005).

LIF, LIFR, and IL6ST are implicated in uterine receptivity to implantation in a number of species including humans, primates, rodents, pigs, cattle, mink, and sheep (see (Auernhammer \& Melmed 2000, Kimber 2005) for a review). In sheep, endometrial LIF 
mRNA decreased from days 12 to 14 and then was most abundant between days 16 and 20 (Vogiagis et al. 1997a). Immunoreactive LIF protein was most abundant in the caruncular and intercaruncular LE, but was also present in GE and intercaruncular stromal cells, as well as in the trophoblast cells of day 17 conceptuses (Vogiagis et al. 1997a). Although LIF may not be obligatory for implantation in ruminants, it does appear to have a role during the establishment of pregnancy (Vogiagis et al. 1997b). During early pregnancy in sheep, hatched blastocysts begin to elongate on day 12 to ultimately form an elongated filamentous conceptus (embryo and associated extraembryonic membranes) of $\sim 19 \mathrm{~cm}$ in length by day 16 (Guillomot 1995, Spencer et al. 2004a). Blastocyst elongation is accompanied by the onset of trophoblast giant binucleate cell differentiation that begins on day 14 (Wooding 1992). Those cells migrate and fuse with the endometrial LE, form the basis of the cotyledonary area of the placentomes, and synthesize a number of hormones such as chorionic somatomammotropin hormone 1 ( $\mathrm{CSH} 1$ or placental lactogen) and progesterone (P4). Blastocyst elongation in sheep requires the uterus and, specifically, secretions from the endometrial epithelia (Gray et al. 2001). Endometrial functions and epithelial secretions during the peri-implantation period of pregnancy in sheep are largely regulated by $\mathrm{P} 4$ from the corpus luteum $(\mathrm{CL})$ and cytokines/hormones from the conceptus, such as interferon tau (IFNT; Spencer et al. 2004b, 2007). IFNT is the signal for maternal recognition of pregnancy in ruminants and is produced between days 10 and 21 of pregnancy in sheep by the mononuclear trophectoderm cells of the conceptus (Spencer et al. 1996, 2007). The anti-luteolytic actions of IFNT are required for the maintenance of a functional $\mathrm{CL}$ and continued secretion of $\mathrm{P} 4$, the essential hormone of pregnancy (Bazer et al. 1997). IFNT also induces or stimulates the expression of a number of genes, termed IFNT-stimulated genes (ISGs), in a cell-specific fashion within the endometrium, with emerging biological roles in uterine receptivity to conceptus development, differentiation, and implantation (Spencer et al. 2008).

Available results support the working hypothesis that LIF from the endometrium and conceptus regulate endometrial function and conceptus development via LIFR and IL6ST. The expression of LIF mRNA and protein in the ovine uterus during early pregnancy has been reported (Vogiagis et al. 1997a, 1997b), but the expression and hormonal regulation of LIFR and IL6ST in the ovine uterus and conceptus during early pregnancy has not been investigated. These studies were conducted to determine effects of 1 ) the estrous cycle and early pregnancy on the expression of LIFR and IL6ST as well as phosphorylated STAT3 in the ovine uterus, 2) P4 and IFNT on LIFR and IL6ST expression in the ovine uterus, and 3) LIF signaling in ovine trophectoderm and endometrial GE cells.

\section{Results}

\section{Effects of the estrous cycle and early pregnancy on the expression of LIFR and IL6ST mRNAs in ovine endometria (study 1)}

Slot-blot hybridization analyses assessed the steady-state levels of ovine LIFR and IL6ST mRNAs in endometria from cyclic and pregnant ewes (Fig. 1). In both cyclic and pregnant ewes, endometrial LIFR mRNA levels increased after day 10 , and the increase was greater in pregnant than cyclic ewes from days 10 to 16 (day $X$ status, $P<0.01)$. In pregnant ewes, endometrial LIFR mRNA levels increased 2.7-fold between days 10 and 14 and remained abundant thereafter (quadratic effect of day, $P<0.01)$. Overall, IL6ST mRNA levels were higher in pregnant than cyclic ewes (status, $P<0.04$ ) and increased 2.8-fold between days 10 and 20 of pregnancy (linear effect of day, $P<0.05$ ).

In situ hybridization analyses determined that LIFR mRNA (Fig. 2) was most abundant in endometrial
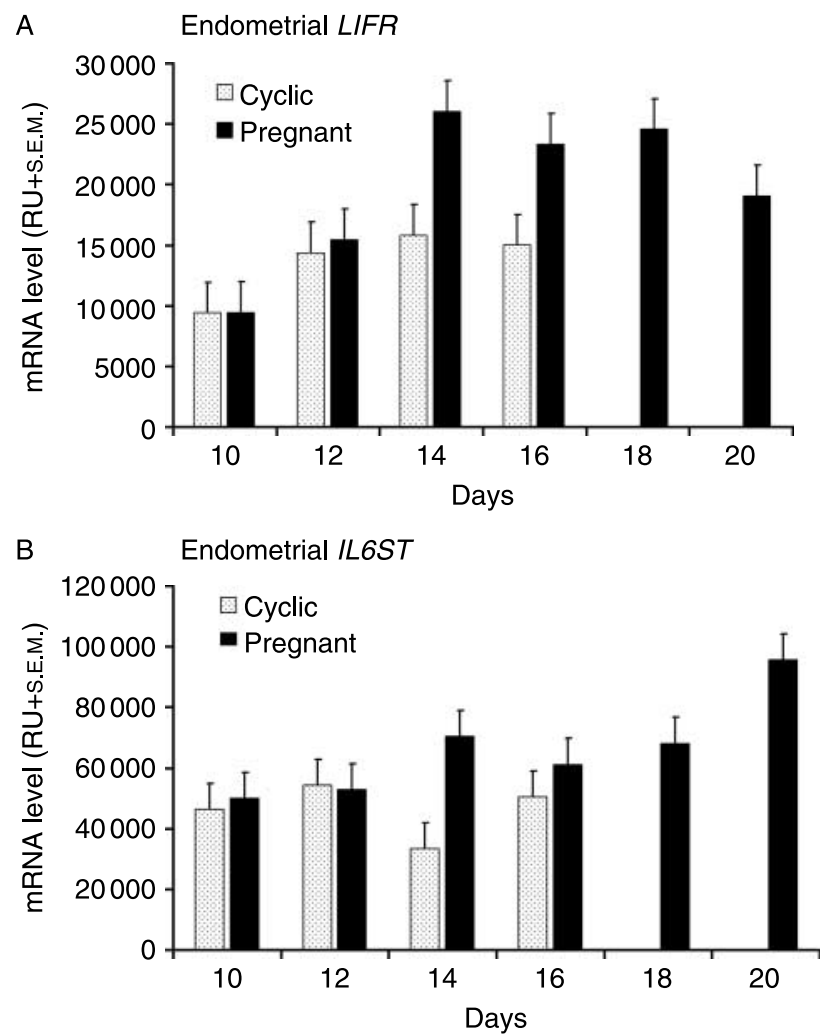

Figure 1 Steady-state levels of LIFR and IL6ST mRNA in endometria from cyclic and early pregnant ewes as determined by slot-blot hybridization analysis. In both cyclic and pregnant ewes, endometrial LIFR mRNA levels increased after day 10 , and the increase was greater in pregnant than cyclic ewes to day 16 (day $\times$ status, $P<0.01$ ). (A) In pregnant ewes, endometrial LIFR mRNA levels increased 2.7-fold between days 10 and 14 and then declined to day 20 (quadratic effect of day, $P<0.01$ ). (B) IL6ST mRNA levels increased 2.8-fold between days 10 and 20 of pregnancy (linear effect of day, $P<0.05)$. Data are expressed as LSM relative units (RU) with S.E.M. 

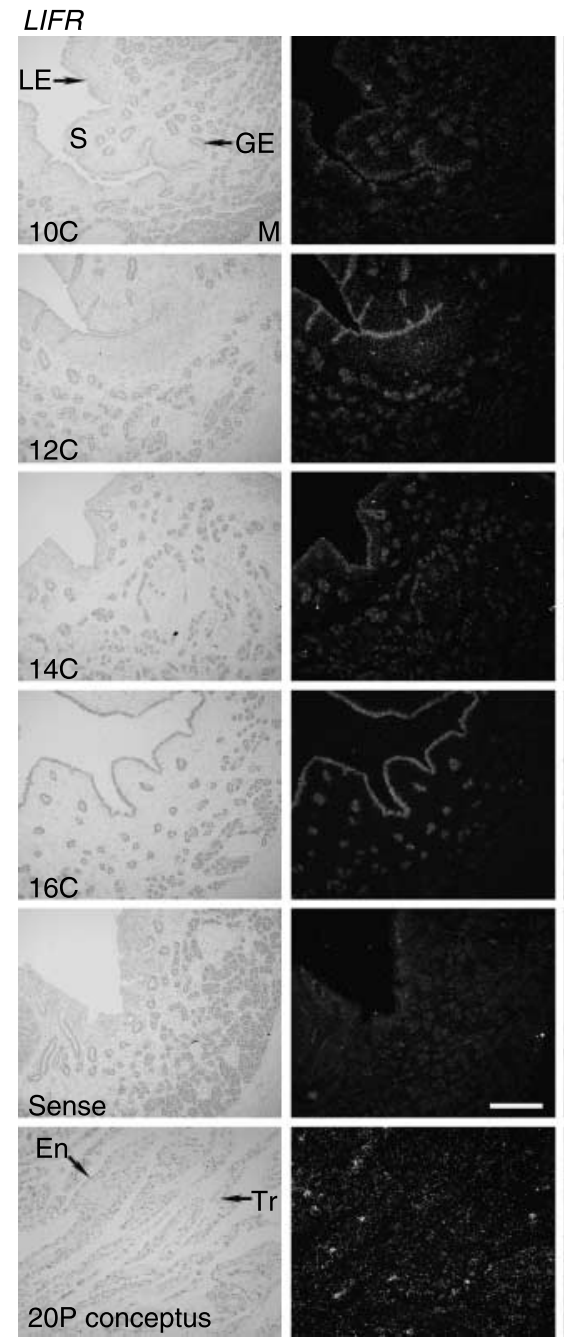

$12 \mathrm{P}$

$14 \mathrm{P}$

$16 \mathrm{P}$

$10 \mathrm{P}$
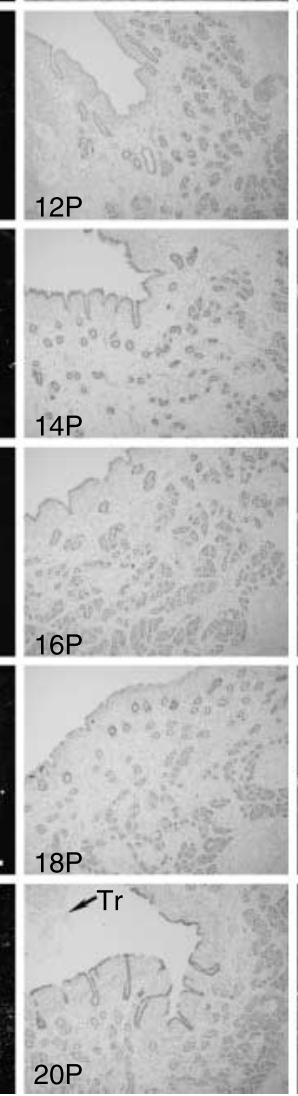
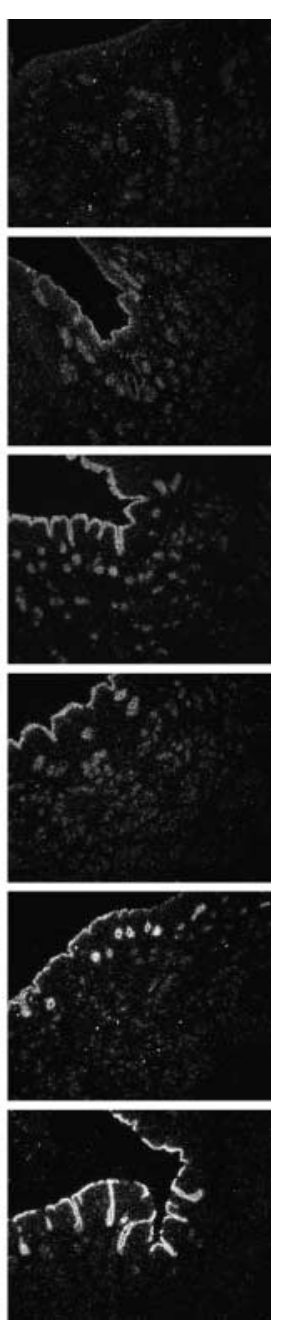

Figure 2 In situ hybridization analysis of LIFR mRNA in the uteri of cyclic and pregnant ewes. Cross sections of the uterine wall from cyclic (C) and pregnant $(\mathrm{P})$ ewes were hybridized with radiolabeled antisense or sense ovine LIFR CRNA probes. LIFR mRNA was present predominantly to the endometrial luminal (LE) and superficial glandular epithelia (sGE). In pregnant ewes, LIFR mRNA increased in endometrial LE/sGE between days 10 and 16 and remained abundant to day 20 . LIFR mRNA was also detected in the trophectoderm of conceptuses on days 18 and 20 of pregnancy. LE, luminal epithelium; GE, glandular epithelium; $S$, stroma; $M$, myometrium;

Tr, trophectoderm; En, endoderm. Scale bar, $25 \mu \mathrm{m}$.
LE/superficial glandular epithelia (sGE) and GE in the upper stratum compactum stroma, whereas IL6ST mRNA (Fig. 3) was most abundant in the middle to deep GE and present at lower abundance in the stroma and LE. In pregnant ewes, LIFR and IL6ST mRNAs increased in endometrial LE/sGE and GE respectively, between days 10 and 16 and remained abundant to day 20. Both LIFR and IL6ST mRNAs were also detected in the trophectoderm of conceptuses on days 18 and 20 of pregnancy. Of particular note is that both LIFR and IL6ST mRNAs were present in the conceptus trophectoderm with IL6ST mRNA being particularly abundant in trophoblast giant binucleate cells (BNC).

\section{Early P4 treatment induces LIFR and IL6ST mRNAs in endometrial epithelia (study 2)}

This study used a sheep model in which exogenous P4 is administered from day 1.5 post-mating, thereby eliciting a premature increase in the circulating levels of P4 that is correlated with a larger blastocyst size on day 9 and the presence of elongated and filamentous conceptuses on day 12, which produce more IFNT (Satterfield et al. 2006). As shown in Fig. 4A and B, for day 9 ewes, endometrial LIFR mRNA abundance was increased twofold by early P4 (CO versus P4, $P<0.03$ ), while IL6ST mRNA was unaffected by this treatment (CO versus P4, $P>0.10)$. In day 12 ewes, LIFR mRNA was also increased (1.6-fold) by P4 (CO versus P4, $P<0.05)$ and IL6ST was not affected (CO versus $\mathrm{P} 4, P>0.10)$. However, treatment of ewes with the antiprogestin RU486 from days 9 to 12 reduced endometrial LIFR mRNA levels by 2.5-fold (P4 versus P4+RU486, $P<0.005$; Fig. 4A) and IL6ST mRNA by 2.8-fold (P4 versus $\mathrm{P} 4+\mathrm{RU}$ 486, $P<0.02$; Fig. 4B) compared with $\mathrm{P} 4$-treated ewes. In situ hybridization analyses revealed that early P4 increased LIFR mRNA in LE and GE (Fig. 4C) and that RU486 treatment reduced both LIFR and IL6ST mRNA in LE/GE and GE of the endometrium respectively (Fig. 4D). 

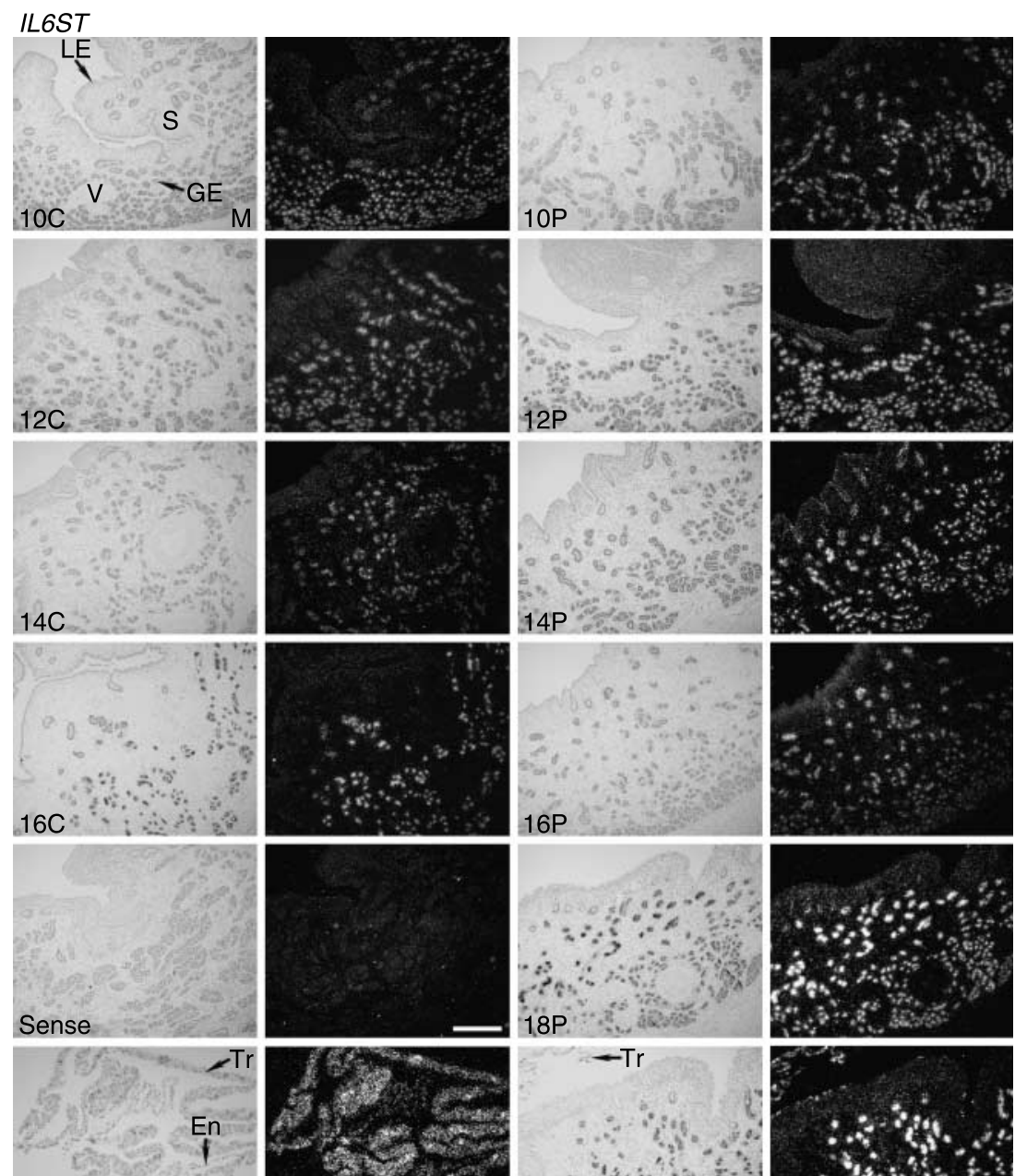

20P conceptus

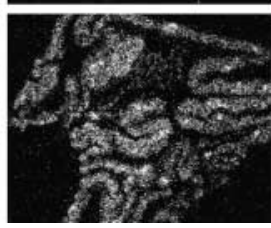

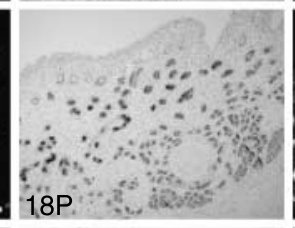

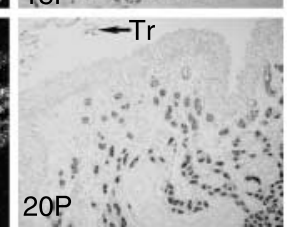

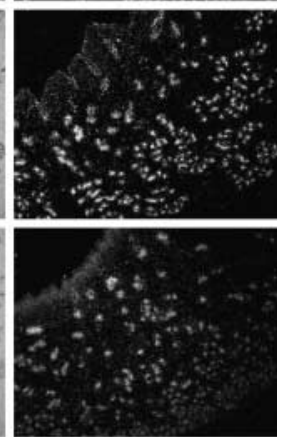
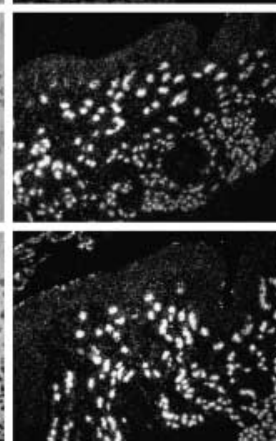

Figure 3 In situ hybridization analysis of IL6ST mRNA in the uteri of cyclic and pregnant ewes. Cross sections of the uterine wall from cyclic (C) and pregnant $(P)$ ewes were hybridized with radiolabeled antisense or sense ovine IL6ST CRNA probes. IL6ST mRNA was present primarily in uterine glandular epithelium (GE). In pregnant ewes, IL6ST mRNA increased in endometrial GE between days 10 and 16 and remained abundant to day 20. Interestingly, on days 18 and 20 of pregnancy, IL6ST mRNA levels were higher in the GE of upper than the deep GE of the endometria. IL6ST mRNA was also detected in the trophectoderm of conceptuses on days 18 and 20 of pregnancy. LE, luminal epithelium; GE, glandular epithelium; S, stroma; M, myometrium; V, blood vessels; Tr, trophectoderm; En, endoderm. Scale bar, $25 \mu \mathrm{m}$.

\section{IFNT stimulates endometrial LIFR and IL6ST expression in ewes treated with P4 (study 3)}

In order to determine whether the expression of LIFR and IL6ST in endometria was regulated by $\mathrm{P} 4$ and/or IFNT, cyclic ewes were ovariectomized and fitted with intrauterine (i.u.) catheters on day 5, treated with exogenous $\mathrm{P} 4$ from days 5 to 16 and given intrauterine infusions of serum proteins as a control (CX) or rolFNT from days 11 to 16. As illustrated in Fig. 5A, LIFR mRNA levels in the endometrium was not affected by $\mathrm{P} 4$ ( $\mathrm{P} 4+\mathrm{CX}$ versus $\mathrm{P} 4+\mathrm{ZK}+\mathrm{CX}, P>0.10)$, whereas IFNT increased LIFR mRNA levels 1.7-fold ( $P 4+C X$ versus $\mathrm{P} 4+\mathrm{IFN}, P<0.04)$ in the ewes treated with $\mathrm{P} 4$, but not in the ewes treated with $\mathrm{P} 4+\mathrm{ZK}$. Endometrial IL6ST mRNA levels were increased 2.3fold by $\mathrm{P} 4$ ( $\mathrm{P} 4+\mathrm{CX}$ versus $\mathrm{P} 4+\mathrm{ZK}+\mathrm{CX}, \mathrm{P}<0.03)$ and an additional 1.5 -fold ( $\mathrm{P} 4+\mathrm{CX}$ versus $\mathrm{P} 4+\mathrm{IFN}$, $P<0.05)$ and 1.4 -fold (P4 + IFN versus $\mathrm{P} 4+\mathrm{ZK}+\mathrm{IFN}$, $P<0.04)$ respectively in both $\mathrm{P} 4-$ and $\mathrm{P} 4+\mathrm{ZK}$-treated ewes (Fig. 5B). In situ hybridization found that IFNT increased LIFR mRNA primarily in LE and SGE (Fig. 5C) and IL6ST mRNA in GE and stroma (Fig. 5D) of the endometrium respectively. In $\mathrm{P} 4+\mathrm{ZK}$ ewes, IFNT increased IL6ST mRNA in the deep GE of the endometrium (Fig. 5D).

\section{Localization of immunoreactive LIFR and IL6ST proteins in the ovine uterus (study 1)}

Immunohistochemical analysis indicated that LIFR protein was localized predominantly to endometrial $\mathrm{LE} / \mathrm{sGE}$, whereas IL6ST protein was localized primarily in uterine LE and GE (Fig. 6). In early pregnant ewes, both LIFR and IL6ST proteins in endometrial epithelia increased after day 14 and were abundant on day 20 of pregnancy (data not shown). Both LIFR and IL6ST proteins were detected in conceptus trophectoderm with IL6ST protein, particularly abundant in trophoblast giant BNC. 


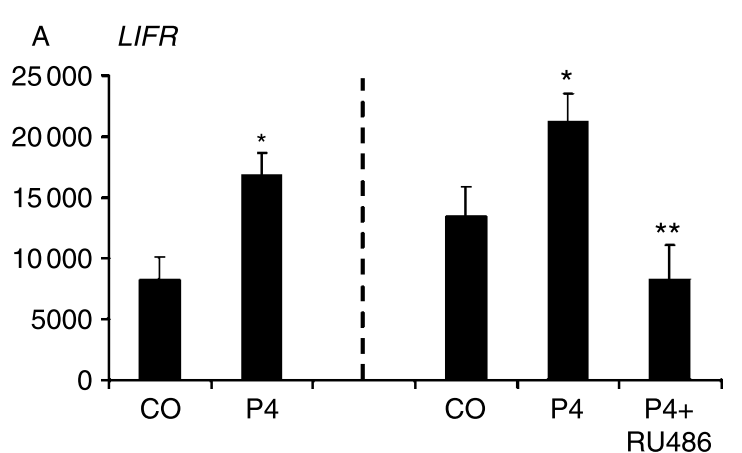

Day 9

C
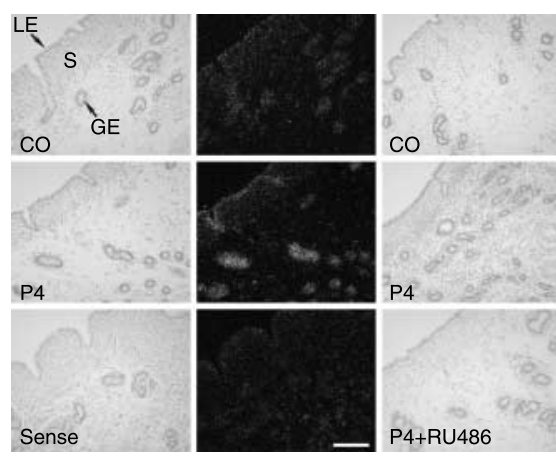

P4

Sense
Day 12

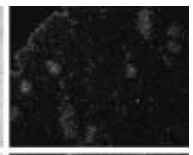

Figure 4 Effects of progesterone (P4) during early pregnancy on LIFR and IL6ST mRNAs in the ovine uterus. (A and B) Steady-state levels of LIFR and IL6ST mRNA in endometria determined by slot-blot hybridization analysis. In ewes treated to day 9, endometrial LIFR mRNA abundance was increased twofold by P4 (CO versus P4, P<0.03), while IL6ST mRNA was unaffected (CO versus P4, P $>0.10$ ). In ewes treated to day 12 , LIFR mRNA was increased 1.6-fold by P4 (CO versus P4, $P<0.05$ ), while IL6ST was not affected (CO versus P4, $P>0.10$ ). Treatment of ewes with the antiprogestin RU486 from days 9 to 12 reduced endometrial LIFR mRNA levels by 2.5-fold (P4 versus P4+RU486, P<0.005) and IL6ST mRNA by 2.8-fold ( $\mathrm{P} 4$ versus $\mathrm{P} 4+\mathrm{RU} 486, P<0.02$ ) compared with $\mathrm{P} 4$-treated ewes. Asterisk denotes an effect of treatment $(* P<0.05, * * P<0.01$ ). (C and D) In situ hybridization analyses of LIFR and IL6ST mRNAs. Cross sections of the uterine wall from treated ewes were hybridized with radiolabeled antisense or sense ovine LIFR and IL6ST CRNA probes. LIFR and IL6ST mRNAs were present at low levels in LE/sGE and in GE respectively of uteri from $\mathrm{P} 4$-treated ewes on day 9 or 12 respectively. LE, luminal epithelium; GE, glandular epithelium; S, stroma. Scale bar, $10 \mu \mathrm{m}$.

\section{Localization of phosphorylated STAT3 protein in ovine endometrium and conceptus}

Immunohistochemical analyses revealed that phosphorylated STAT3 ( $p$-STAT3) protein was present in most endometrial cell types in cyclic and pregnant ewes, but was particularly abundant in the nuclei of endometrial epithelia (Fig. 7A). In uterine LE, p-STAT3 protein increased between days 10 and 12, remained maximal from days 12 to 16 , and declined thereafter in pregnant ewes. In the upper GE, p-STAT3 protein increased substantially between days 16 and 18 of pregnancy (Fig. 7A and B). The p-STAT3 protein was also abundant in conceptus trophectoderm and detected in the endoderm (Fig. 7C).

\section{IFNT increase LIFR and IL6ST proteins in ovine trophoblast cells}

In oTr 1 cells, IFNT increased amounts of LIFR (190 kDa) and IL6ST $(130 \mathrm{kDa})$ proteins by 1.9 -fold $(P<0.05)$ and 2.2 -fold $(P<0.01)$ respectively over basal levels

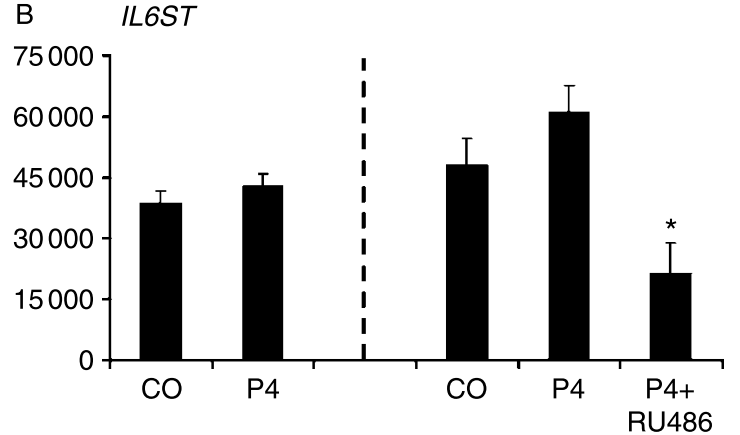

D

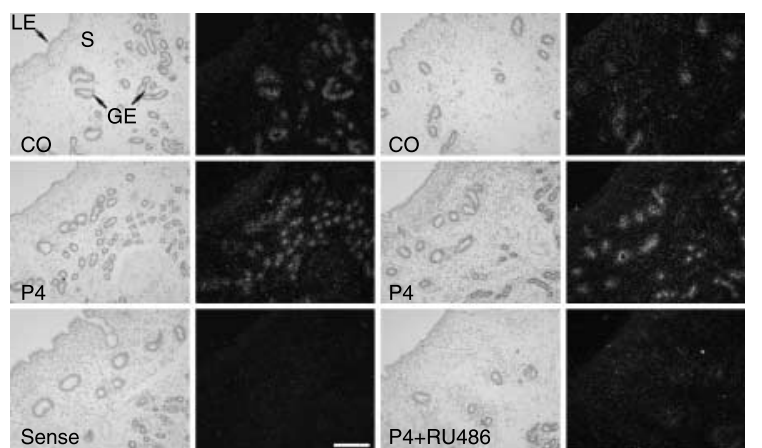

at 24-h post-treatment (Fig. 8A and B). In oGE cells, both LIFR and IL6ST proteins were present at all time points, but not affected $(P>0.10)$ by IFNT (Fig. 9A and $\mathrm{B})$.

\section{LIF activates STAT3 and MAPK3/1 MAPK phosphorylation in ovine trophoblast and glandular epithelial cells}

The oTr 1 cells were untreated or treated with LIF for $15 \mathrm{~min}$ and then phosphorylated and total STAT3 and MAPK3/1 (p42/p44) MAPK proteins detected in cell lysates by immunoblotting. As shown in Fig. 8C and D, LIF increased the abundance of both p-STAT3 and p-MAPK3/1 MAPK proteins. In response to treatment with $100 \mathrm{ng} / \mathrm{ml}$ of recombinant LIF, p-STAT3 abundance increased 5.3-fold $(P<0.01)$ over basal levels within $5 \mathrm{~min}$ and then decreased to basal levels by $60 \mathrm{~min}$ (Fig. 8E). Meanwhile, LIF stimulated a rapid 5.6-fold $(P<0.01)$ increase in p-MAPK3/1 MAPK abundance within 15 min that decreased to basal levels between 30 and $60 \mathrm{~min}$ (Fig. 8F). In oGE cells, rolFNT did not affect the abundance 

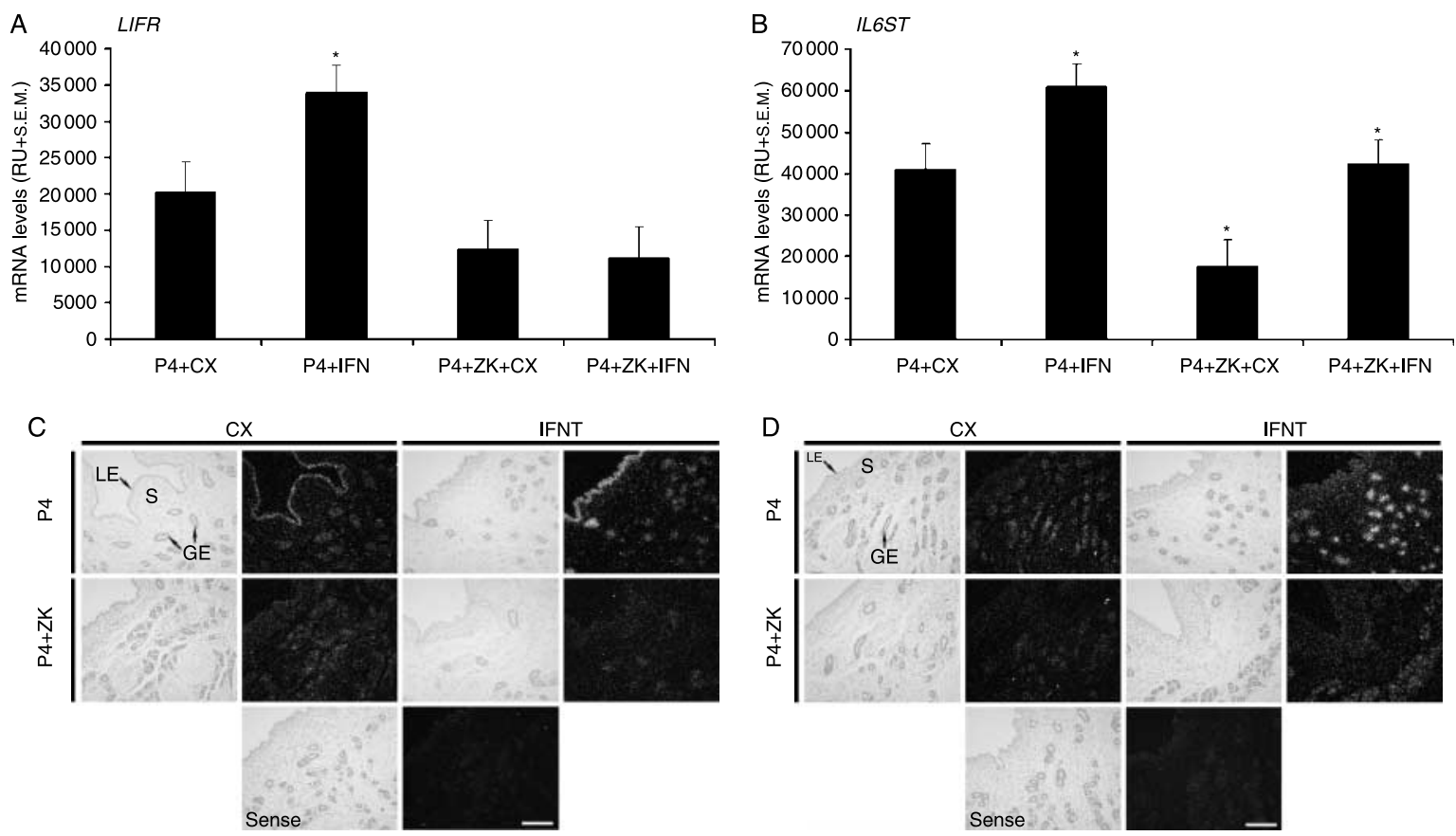

Figure 5 Effects of progesterone (P4) and IFNT on LIFR mRNA in the ovine uterus. (A and B) Steady-state levels of LIFR and IL6ST mRNA in endometria as determined by slot-blot hybridization analysis. Endometrial LIFR mRNA was not affected by P4 (P4 +CX versus P4+ZK + CX, $P>0.10$ ). However, rolFNT infusion increased $L I F R$ mRNA levels by 1.7 -fold ( $P 4+C X$ versus $P 4+I F N, P<0.04)$, but not in $P 4+Z K$-treated ewes. IL6ST mRNA levels were increased 2.3 -fold by P4 ( $\mathrm{P} 4+\mathrm{CX}$ versus $\mathrm{P} 4+\mathrm{ZK}+\mathrm{CX}, P<0.03$ ), and rolFNT increased IL6ST mRNA abundance 1.5 -fold $(\mathrm{P} 4+\mathrm{CX}$ versus $\mathrm{P} 4+$ rolFNT, $P<0.05)$ and 1.4 -fold $(\mathrm{P} 4+$ rolFNT versus $\mathrm{P} 4+\mathrm{ZK}+$ rolFNT, $P<0.04)$ respectively in both $\mathrm{P} 4$ - and $\mathrm{P} 4+\mathrm{ZK}$-treated ewes. Asterisk denotes an effect of treatment $\left({ }^{*} P<0.05\right)$. (C and D) In situ hybridization revealed that IFNT increased LIFR mRNA primarily in the LE and IL6ST mRNA in the GE and stroma of the endometrium respectively. In P4+ZK ewes, IFNT increased IL6ST mRNA in the deep GE of the endometrium. LE, luminal epithelium; GE, glandular epithelium; S, stroma. Scale bar, $10 \mu \mathrm{m}$.

of LIFR or IL6ST proteins (Fig. 9A and B). However, LIF increased the levels of p-STAT3 and p-MAPK3/1 MAPK proteins by 6.1 -fold $(P<0.01)$ and 3.6 -fold $(P<0.01)$ over basal levels respectively within 5 min; the effect was maintained to $90 \mathrm{~min}$ (Fig. 9C and D).

\section{Discussion}

The present studies revealed that both LIFR and IL6ST expression in the ovine endometrium increases during the peri-implantation period of early pregnancy. Coexpression of LIFR and IL6ST mRNA and protein as well as phophorylated (activated) STAT3 protein was primarily in the superficial and upper glands of the endometrium, as well as in the trophectoderm of the conceptus. Vogiagis et al. (1997a) found that LIF mRNA and protein were present in relatively constant amounts throughout the estrous cycle and early pregnancy in sheep and localized to all uterine cell types with particular abundance in the $L E$, and that immunoreactive LIF was present in conceptus trophectoderm. Thus, the paracrine and perhaps autocrine actions of LIF within the uterus during early pregnancy in sheep are most likely manifest on the upper glands of the endometrium and conceptus trophectoderm. The results of the present studies indicate that the biological effects of LIF on those cells involve activation of STAT3 and MAPK3/1 MAPK signaling pathways to alter gene expression patterns and cell proliferation and differentiation.

The results of the present study found that LIFR and IL6ST in the endometrial LE/GE and GE respectively are stimulated by P4 and IFNT in a complex stage- and cellspecific manner. The induction of many genes by $\mathrm{P} 4$, such as galectin 15 (LGALS15; Gray et al. 2004), cathepsin L1 (CTSL1; Song et al. 2005), cystatin C (CST3; Song et al. 2006a), endothelial PAS domain protein 1 (EPAS1; Song et al. 2008a), gastrin-releasing peptide (GRP; Song et al. 2008b), and insulin-like binding proteins 1 and 3 (IGFBP1 and IGFBP3; Satterfield et al. 2008), in the endometrial LE/sGE of the ovine uterus appears to be indirect and require $\mathrm{P} 4$ induced down-regulation of $\mathrm{P} 4$ receptors (PGR) in those epithelia (Spencer et al. 2004b, 2007), as well as perhaps factors from PGR-positive uterine stromal cells, such as fibroblast growth factor 10 (FGF10; Chen et al. 2000, Satterfield et al. 2008). Indeed, the increase in LIFR mRNA abundance in the LE/sGE and upper GE between days 10 and 14 post-estrus/mating in study 1 is coincident with the loss of PGR mRNA and protein in these epithelia (Wathes \& Hamon 1993, Spencer et al. 1995). Furthermore, in studies 2 and 3, LIFR mRNA increased in endometrial LE/sGE and upper GE of 

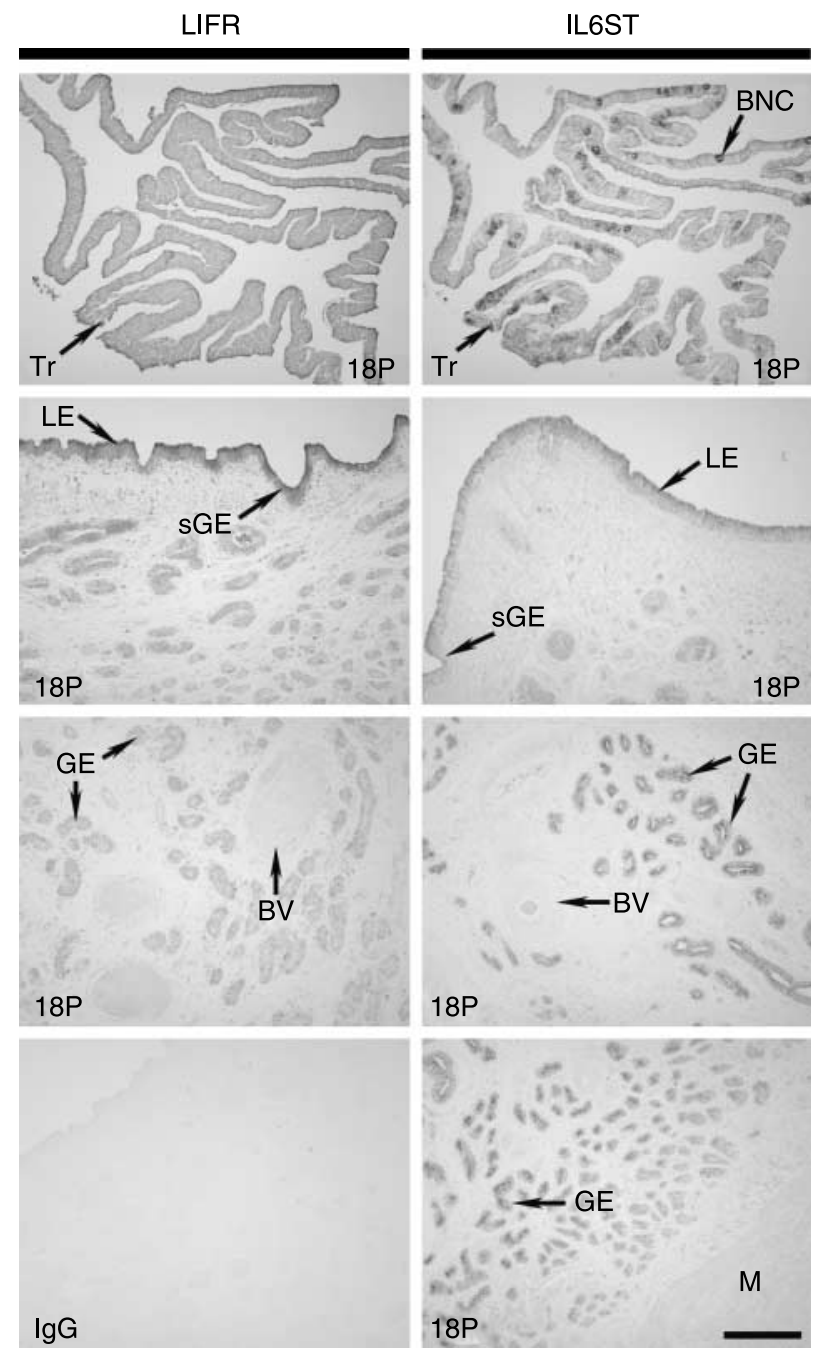

Figure 6 Immunolocalization of LIFR and IL6ST proteins in the uteri from cyclic and pregnant ewes. Immunoreactive LIFR and IL6ST proteins were localized predominantly near the apical surface of endometrial LE/sGE and all GE respectively in uteri and in conceptus trophectoderm from day 18 pregnant ewes using a rabbit anti-human LIFR polyclonal antibody and a rabbit anti-human gp130 polyclonal antibody. For the IgG control, normal rabbit IgG was substituted for the primary antibody. Sections were not counterstained. $L E$, luminal epithelium; GE, glandular epithelium; Tr, trophectoderm; M, myometrium; BV, blood vessels; sGE, superficial GE; BNC, binucleate cells. Scale bar, $10 \mu \mathrm{m}$.

P4-treated ewes, but not in the ewes treated with $\mathrm{P} 4$ and a PGR antagonist, i.e., ZK 136317 or RU486. Continuous exposure of the sheep uterus to P4 for 8-10 days down-regulates $P G R$ mRNA and protein in endometrial $\mathrm{LE} / \mathrm{sGE}$, but not in stroma or myometrium (Johnson et al. 2000b); however, PGR are present in the endometrial epithelia of the ewes treated with P4 and a PGR antagonist (Johnson et al. 2000b), because PGR antagonists prevent P4 from down-regulating the expression of PGR. Consequently, the increase in LIFR mRNA may be due to P4-induced down-regulation of PGR in LE/sGE between days 10 and 12 of the estrous cycle and pregnancy (Spencer \& Bazer 2004, Spencer et al. 2004b). The increase in endometrial LIFR expression by early treatment with $\mathrm{P} 4$ in study 2 also occurred coincident with early loss of PGR by endometrial LE/sGE (Satterfield et al. 2006). Similarly, IL6ST is expressed predominantly in endometrial GE as is the case for secreted phosphoprotein 1 (commonly referred to as osteopontin), serpin peptidase inhibitor (also known as uterine milk protein or UTMP), stanniocalcin 1 (STC1), and GRP, which encode proteins secreted into the uterine lumen (Moffatt et al. 1987, Ing \& Roberts 1989, Johnson et al. 1999b, 2003, Song et al. 2006b, $2008 b$ ). All four of those genes are induced in endometrial GE by the long-term effects of continuous P4 that also requires loss of the PGR as a permissive event preceding IFNT effects to enhance gene expression (Spencer \& Bazer 2002, Spencer et al. 2004b). Collectively, available evidence supports the idea that treatment of ewes with PGR antagonists prevents P4induced loss of PGR in the LE/sGE and GE, as well as stromal-derived progestomedins, and then subsequent induction of gene expression in those epithelia, which, in turn, produces a uterus unsupportive of conceptus development and implantation. Indeed, no blastocysts were recovered from the P4+RU486-treated ewes in study 2 that had reduced the levels of endometrial LIFR and IL6ST expression (Satterfield et al. 2006). In addition to being an antiprogestin, RU486 or mifepristone is a high-affinity antagonist of the nuclear receptor subfamily 3, group C, member 1 (glucocorticoid receptor; NR3C1, also known as GR; Baulieu 1989), suggesting that $\mathrm{NR} 3 \mathrm{C} 1$ and glucocorticoids may also regulate uterine $\mathrm{LE} / \mathrm{sGE}$ gene expression. However, little is known of $N R 3 C 1$ expression and glucocorticoid effects within the ovine uterus during early pregnancy.

Available results support our working hypothesis that uterine LIF regulates endometrial function and conceptus growth and development during the periimplantation period of pregnancy in sheep. In the present study, LIFR, IL6ST, and phosphorylated STAT3 were found in the upper GE of early pregnancy during the period of conceptus elongation and implantation. Similarly, Lifr and II6st are co-expressed in the uterine LE of mice (Song \& Lim 2006), which responds to LIF from the endometrial GE by phosphorylating STAT3 that is essential for implantation (Cheng et al. 2001, Song \& Lim 2006). In the present studies, treatment of ovine endometrial GE cells with LIF increased the abundance of activated phosphorylated STAT3 and MAPK3/1 MAPK proteins. Future studies will determine which genes in the upper GE are the targets of LIF actions.

Novel results from the present studies implicate LIF, LIFR, IL6ST co-receptor, and STAT3 and MAPK3/1 MAPK in the growth and differentiation of conceptus trophectoderm and, in particular, trophoblast giant BNC. In particular, LIFR signaling via STAT3 regulates trophoblast giant cell differentiation in mice (Takahashi et al. 2008). 


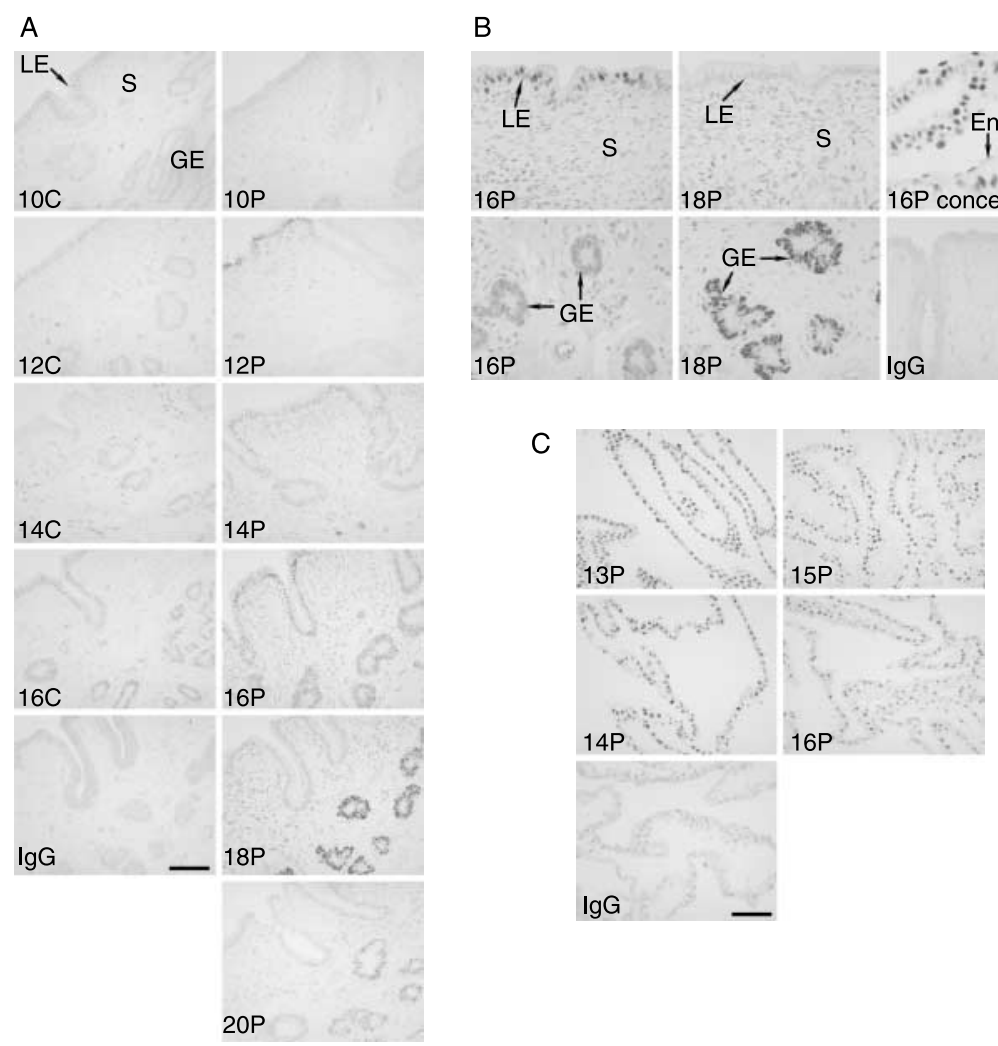

Figure 7 Immunohistochemical localization of phosphorylated STAT3 protein in endometria from cyclic and pregnant ewes. Immunoreactive p-STAT3 protein was localized using a rabbit antimouse phospho-STAT3 (Tyr705) polyclonal antibody. Normal rabbit IgG was substituted for the primary antibody as a negative control. Sections were not counterstained. Immunoreactive $\mathrm{p}$-STAT3 protein was present in the nuclei of endometrial LE, GE, and conceptus trophectoderm of pregnant ewes. Interestingly, after day 16 of pregnancy, p-STAT3 protein was predominantly localized to the endometrial upper glands while significantly decreased in the LE. The p-STAT3 protein was also particularly abundant in conceptus trophectoderm in pregnant ewes. Localization of immunoreactive $p$-STAT3 protein in conceptus trophectoderm, including binucleate giant cells, was based on cell morphology. $\mathrm{LE}$, luminal epithelium; GE, glandular epithelium; $\mathrm{S}$, stroma; En, endoderm; Tr, trophectoderm. (A and C) Scale bar, $5 \mu \mathrm{m}$; (B) $2.5 \mu \mathrm{m}$.

Indeed, the polyploid trophoblast giant cells of the mouse placenta are terminally differentiated and mediate trophoblast invasion of maternal decidua (Simmons \& Cross 2005). Similarly, human extravillous trophoblast invasiveness can be regulated by LIF and STAT3 (Poehlmann et al. 2005). The trophoblast giant BNC of the ovine placenta are similar to the trophoblast giant cells of the mouse placenta, in that they are polyploid, invasive, and express unique genes such as $\mathrm{CSH} 1$ (Hoffman \& Wooding 1993). In addition to STAT3, the MAPK3/1 MAPK pathway also plays important roles in differentiation, including embryonic and placental development (Mudgett et al. 2000, Wang et al. 2004, Daoud et al. 2005). Given that little is known about the cellular and molecular mechanisms governing trophoblast growth and differentiation in ruminants, the potential roles of LIF, its receptor complex, STAT3, and MAPK3/1 MAPK in development and differentiation within the sheep conceptus need to be discerned.

\section{Materials and Methods}

\section{Animals}

Mature crossbred Suffolk sheep (Ovis aries) were observed daily for estrus in the presence of vasectomized rams and used in experiments after they had exhibited at least two estrous cycles of normal duration (16-18 days). At estrus, the ewes were assigned randomly to cyclic or pregnant status. All experimental and surgical procedures were in compliance with the Guide for the Care and Use of Agriculture Animals in Teaching and Research and were approved by the Institutional Animal Care and Use Committee of Texas A\&M University.

\section{Experimental design}

Study 1

At estrus (day 0), the ewes were mated to either an intact or vasectomized ram and then hysterectomized ( $n=5$ ewes/day) on either day $10,12,14$, or 16 of the estrous cycle or day 10 , $12,14,16,18$, or 20 of pregnancy as described previously (Spencer et al. 1999a). At hysterectomy, the uterus was flushed with $20 \mathrm{ml}$ sterile saline. Pregnancy was confirmed on days 10-16 post-mating by the presence of a morphologically normal conceptus(es) in the uterine flushing. It was not possible to obtain uterine flushings on either day 18 or 20 of pregnancy, because the conceptus had firmly adhered to the endometrial LE and basal lamina. At hysterectomy, several sections $(\sim 0.5 \mathrm{~cm})$ from the mid-portion of each uterine horn ipsilateral to the $\mathrm{CL}$ were fixed in fresh $4 \%$ paraformaldehyde in PBS $(\mathrm{pH}$ 7.2) $(\mathrm{v} / \mathrm{v})$. After $24 \mathrm{~h}$, the fixed tissues were changed to $70 \%$ ethanol $(\mathrm{v} / \mathrm{v})$ for $24 \mathrm{~h}$, dehydrated through a graded series of alcohol to xylene, and then embedded in Paraplast Plus (Oxford Labware, St Louis, MO, USA). The remaining endometrium was physically dissected from myometrium, frozen in liquid nitrogen, and stored at $-80^{\circ} \mathrm{C}$ for subsequent RNA extraction. In monovulatory pregnant ewes, uterine tissue samples were marked as either contralateral or ipsilateral to the ovary bearing the $\mathrm{CL}$ and only tissues from the ipsilateral 


\section{A}
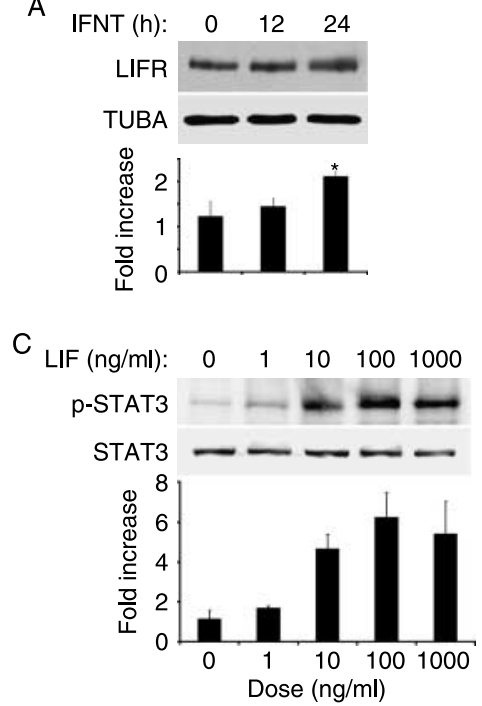

E

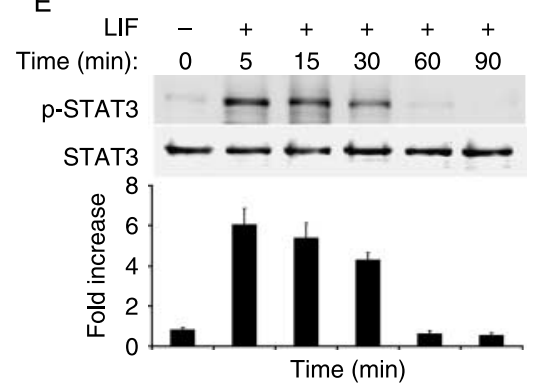

B

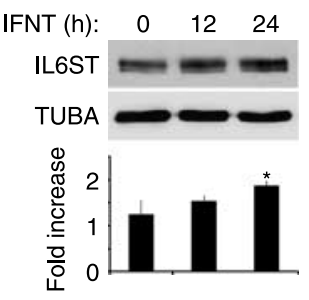

$\mathrm{D}$

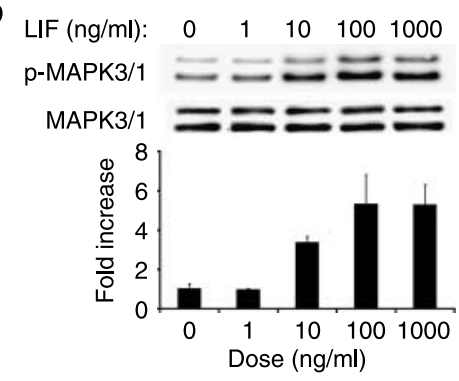

F

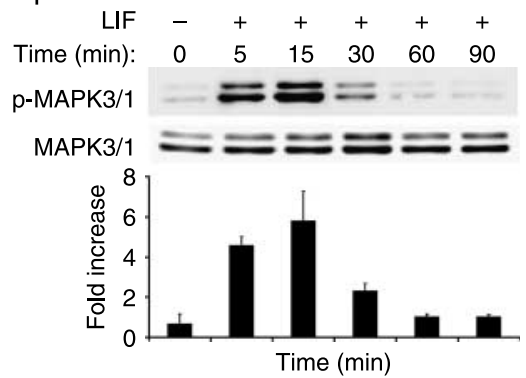

Figure 8 Effects of IFNT on LIFR and IL6ST proteins and dose- and time-dependent effects of human LIF on the phosphorylation of STAT3 and MAPK3/1 MAPK in ovine trophectoderm (oTr1) cells. (A and B) The oTr1 cells were starved for $24 \mathrm{~h}$ in serum-free medium and then treated with IFNT $\left(10^{4} \mathrm{AVU} / \mathrm{ml}\right)$ for the indicated periods of time. Blots were imaged to calculate the normalized values presented in graphs (bottom) by measurements of the levels of mouse $\alpha$-tubulin (TUBA) protein relative to total proteins. This time-course design was replicated in four independent experiments. (C-F) oTr1 cells were starved for $24 \mathrm{~h}$ in serum-free medium and then treated with LIF by indicated concentration (C and D) and time (100 ng/ml LIF) (E and F). Blots were imaged to calculate the normalized values presented in graphs by measurements of the levels of phosphorylated protein relative to total proteins. All quantitative data are presented as least-squares means (LSM) with overall S.E.M. This time-course design was replicated in three independent experiments. uterine horn were used in subsequent analyses. In addition, conceptuses ( $n>5$ per day) were collected on days 13, 14, 15, and 16 of pregnancy by uterine flush and then fixed and embedded in paraffin as described above.

\section{Study 2}

As described previously (Satterfield et al. 2006), the ewes were mated at estrus (day 0) to intact rams and then assigned randomly to receive daily i.m. injections from days 1.5 to 9 of either corn oil vehicle (CO; $n=6)$ or $25 \mathrm{mg}$ P4 $(n=6)$. All ewes were hysterectomized on day 9 , and uteri processed as described for experiment 1 . In a complementary study, the ewes were mated and assigned randomly to receive daily i.m. injections of either (a) CO $(n=8)$, (b) $25 \mathrm{mg}$ P4 (Sigma Chemical Co.) from days 1.5 to $12(n=7)$, or (c) $25 \mathrm{mg} \mathrm{P} 4$ (from days 1.5 to $8, n=5$ ) and $75 \mathrm{mg}$ of RU486 (mifepristone; Sigma-Aldrich Inc.), a P4 receptor (PGR) antagonist, from days 8 to 12 (P4 + RU486). All ewes were hysterectomized on day 12 , and uteri processed as described for study 1 . Pregnancy was confirmed by the recovery of a morphologically normal blastocyst or conceptus in the uterine flushing.

\section{Study 3}

Cyclic ewes $(n=20)$ were checked daily for estrus and then ovariectomized and fitted with indwelling uterine catheters on day 5 as described previously (Johnson et al. 2000a). The ewes were then assigned randomly ( $n=5$ per treatment) to receive daily i.m. injections of P4 and/or a PGR antagonist (ZK 136,317; Schering AG, Berlin, Germany) and intrauterine (i.u.) infusions of control serum proteins and/or recombinant ovine IFNT protein (rolFNT) as follows: 1) $50 \mathrm{mg} \mathrm{P4}$ (days 5-16) and $200 \mu \mathrm{g}$ control serum (CX) proteins (days 11-16) (P4 + CX), 2) P4 plus $75 \mathrm{mg}$ ZK 136,317 (days 11-16) and CX proteins (P4+ $\mathrm{ZK}+\mathrm{CX})$, 3) P4 and IFNT $\left(2 \times 10^{7}\right.$ antiviral units, days $\left.11-16\right)$ (P4+IFN), or 4) P4 plus ZK and IFNT (P4+ZK+IFN). Steroids were administered i.m. daily in corn oil vehicle. Both uterine horns of each ewe received twice daily injections of either $\mathrm{CX}$ proteins ( $50 \mu \mathrm{g} / \mathrm{horn} /$ injection) or rolFNT $\left(5 \times 10^{6}\right.$ antiviral units/ horn/injection). The rolFNT was produced in Pichia pastoris and purified as described previously (Van Heeke et al. 1996). CX proteins were prepared for intrauterine injection as described previously (Spencer et al. 1995). This regimen of P4 and rolFNT mimics the effects of $\mathrm{P} 4$ from the $\mathrm{CL}$ and IFNT from the conceptus on endometrial expression of hormone receptors and ISGs during early pregnancy in sheep (Song et al. 2005, 2006a, $2007,2008 a, 2008$ b). All ewes were hysterectomized on day 17 , and uteri processed as described for study 1 .

\section{Study 4}

A mononuclear ovine trophectoderm cell line (oTr1), derived from a day 15 conceptus (Farmer et al. 2008, Kim et al. 2008), 
A

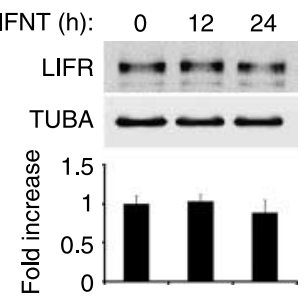

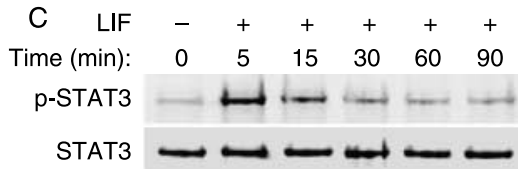

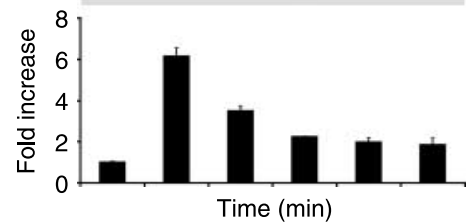

B IFNT (h): $0 \quad 12 \quad 24$

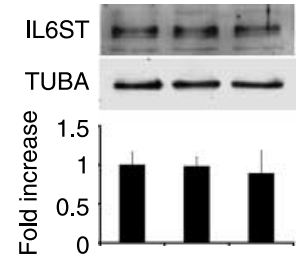

D $\mathrm{LIF} \quad-\quad+\quad+\quad+\quad+\quad+$

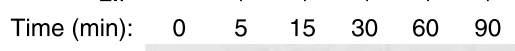

p-MAPK3/1 $= \pm \geq=$
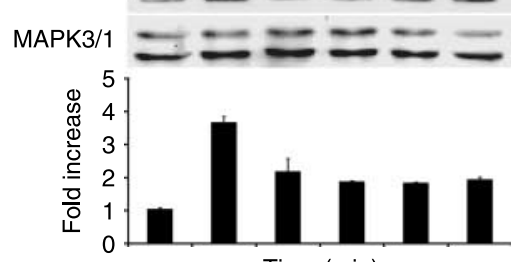

Figure 9 Dose- and time-dependent effects of human LIF on phosphorylation of STAT3 and MAPK3/1 MAPK in an immortalized ovine uterine glandular epithelial (OGE) cell line. (A and B) The oGE cells were starved for $24 \mathrm{~h}$ in serum-free medium and then treated with IFNT $\left(10^{4} \mathrm{AVU} / \mathrm{ml}\right)$ for the indicated periods of time. Blots were imaged to calculate the normalized values presented in graphs (bottom) by measurements of the levels of mouse $\alpha$-tubulin (TUBA) protein relative to total proteins. This time-course design was replicated in four independent experiments. (C and D) The oGE cells were starved for $24 \mathrm{~h}$ in serum-free medium and then treated with LIF by indicated time $(100 \mathrm{ng} / \mathrm{ml} \mathrm{LIF})$. Blots were imaged to calculate the normalized values presented in graphs by measurements of the levels of phosphorylated protein relative to total proteins. All quantitative data are presented as least-squares means (LSM) with overall S.E.M. This time-course design was replicated in three independent experiments.

was cultured as described previously in DMEM-F12 (SigmaAldrich Corp.) that included $10 \%$ FBS $(\mathrm{v} / \mathrm{v}), 50 \mathrm{U}$ penicillin, $50 \mu \mathrm{g}$ streptomycin, $0.1 \mathrm{mM}$ each non-essential amino acids, $1 \mathrm{mM}$ sodium pyruvate, $2 \mathrm{mM}$ glutamine, and $0.7 \mu \mathrm{M}$ insulin. When cell density in dishes reached about $80 \%$ confluence, they were passaged at a ratio of $1: 3$ and frozen stocks of cells were prepared at each passage. For experiments, monolayer cultures of oTr1 cells (between passages 9 and 13) were grown in culture medium to $80 \%$ confluence on $100 \mathrm{~mm}$ tissue culture plates. Immortalized ovine endometrial GE (oGE) cells were cultured as described previously (Johnson et al. 1999a). Ovine GE cells were maintained in DMEM-F12 supplemented with $10 \%$ FBS (v/v) and antibiotics and then both cell monolayer cultures were grown to $90 \%$ confluence on $100 \mathrm{~mm}$ tissue culture plates. All cell lines were incubated in serum-free medium for $24 \mathrm{~h}$ and then left untreated as a control or treated with rolFNT $\left(10^{4} \mathrm{AVU} / \mathrm{ml}\right)$ for the indicated time. In other experiments, oTr1 and oGE cells were serum starved for $24 \mathrm{~h}$ and then treated with recombinant human LIF (rhLIF, catalog no. L-5283; Sigma-Aldrich Inc.) for 0, 5, 15, 30, 60 , or $90 \mathrm{~min}$. Based on dose-response experiments (tested concentrations of 1, 10, 100, and $1000 \mathrm{ng} / \mathrm{ml} \mathrm{LIF)} \mathrm{with} \mathrm{doses}$ based on bovine embryo culture conditions (Fukui \& Matsuyama 1994, Han et al. 1995, Funston et al. 1997, Sirisathien et al. 2003), the $100 \mathrm{ng} / \mathrm{ml}$ dose of LIF was selected and used for study. All studies were replicated in three independent experiments.

\section{RNA isolation}

Total cellular RNA was isolated from the frozen endometria or cultured cells using the TRIzol reagent (Gibco-BRL), according to the manufacturer's recommendations. The quantity and quality of total RNA were determined by spectrometry and denaturing agarose gel electrophoresis respectively.

\section{Cloning of partial CDNAs for ovine LIFR and IL6ST}

Partial cDNAs for ovine LIFR and IL6ST mRNAs were amplified by RT-PCR using total RNA from day 18 pregnant endometrium using specific primers based on bovine LIFR mRNA (GenBank accession no. XM_587754; forward, 5'-AGC CAC TGA CCG AGT TTC C- $3^{\prime}$; reverse, $5^{\prime}$-ATG GGA AGA AAT TCC TGT GG-3') and bovine IL6ST mRNA (GenBank accession no. XM-600430; forward, 5'-TCC TGG AAG GGA AAC ATA CC-3'; reverse, 5' GCT TCT TCA CTC CAG TCA CTC C-3'). Reverse transcription of total RNA into cDNA was performed as described previously (Taylor et al. 2001). PCR amplification was conducted as follows for LIFR and IL6ST: 1) $95^{\circ} \mathrm{C}$ for $5 \mathrm{~min}$; 2) $95^{\circ} \mathrm{C}$ for $30 \mathrm{~s}, 56.5^{\circ} \mathrm{C}$ for $40 \mathrm{~s}$, and $72{ }^{\circ} \mathrm{C}$ for $1 \mathrm{~min}$ for 35 cycles; and 3) $72{ }^{\circ} \mathrm{C}$ for $10 \mathrm{~min}$. The partial cDNAs for ovine LIFR and IL6ST PCR products were cloned into pCRII using a T/A Cloning Kit (Invitrogen) and their sequences verified using an ABI PRISM Dye Terminator Cycle Sequencing Kit and ABI PRISM automated DNA sequencer (Applied Biosystems, Foster City, CA, USA).

\section{Slot-blot hybridization analyses}

The steady-state levels of mRNA in ovine endometria were assessed by radioactive slot-blot hybridization as described previously (Spencer et al. 1999b). Denatured total endometrial RNA $(20 \mu \mathrm{g})$ from each ewe was hybridized with radiolabeled antisense cRNA probes. To correct for variation in total RNA loading, a duplicate RNA slot-blot membrane was hybridized with radiolabeled antisense 18S cRNA (pT718S; Ambion, Austin, TX, USA), because 18S RNA content of the endometrium was not affected by day, pregnancy status, or hormonal treatment in any of the studies (data not shown). Following washing, the blots were digested with RNase A and radioactivity associated with slots quantified using a Typhoon 8600 Multilmager (Molecular Dynamics, Piscataway, NJ, USA). 


\section{In situ hybridization analyses}

Location of mRNA in uterine sections $(5 \mu \mathrm{m})$ was determined by radioactive in situ hybridization analysis as described previously (Spencer et al. 1999b). After hybridization, washing and RNase A digestion, slides were dipped in NTB-2 liquid photographic emulsion (Kodak), and exposed at $4{ }^{\circ} \mathrm{C}$ for 10 days. After development and counterstaining, images of the representative fields were recorded under bright- or darkfield illumination.

\section{Immunohistochemical analyses}

Immunohistochemical localization of LIFR and IL6ST proteins in ovine uteri was performed as described previously (Spencer et al. 1999c) using rabbit anti-human LIFR polyclonal IgG (catalog no. sc-659; Santa Cruz Biotechnology Inc., Santa Cruz, CA, USA) at 1:500 dilution $(0.4 \mu \mathrm{g} / \mathrm{ml})$, rabbit antihuman IL6ST polyclonal IgG (catalog no. 06-261; Upstate, Lake Placid, NY, USA) at 1:1000 dilution $(1.0 \mu \mathrm{g} / \mathrm{ml})$, and rabbit anti-mouse phospho-STAT3 (Tyr705) polyclonal IgG (catalog no. 9131; Cell Signaling Technology, Danvers, MA, USA) at 1:100 dilution. Antigen retrieval was performed using the boiling citrate method. Negative controls included substitution of the primary antibody with purified non-immune rabbit IgG at the same final concentration. Sections were not counterstained prior to affixing coverslips.

\section{Western blot analyses}

Whole cell extracts and immunoblot assays were prepared and performed as described previously (Stewart et al. 2001). Proteins in cell lysates were denatured, separated using SDSPAGE, transferred to nitrocellulose, and western blot analyses performed as described previously (Spencer et al. 1999a) using ECL detection (SuperSignal West Pico, Pierce, Rockford, IL, USA) and X-OMAT AR X-ray film (Kodak), according to the manufacturer's recommendations. Immunoreactive proteins were detected using anti-human LIFR polyclonal IgG (catalog no. sc-659; Santa Cruz Biotechnology Inc.) at 1:1000 dilution $(0.2 \mu \mathrm{g} / \mathrm{ml})$, anti-human IL6ST polyclonal IgG (catalog no. 06261; Upstate) at $1: 2000$ dilution $(0.5 \mu \mathrm{g} / \mathrm{ml})$, anti-mouse phospho-STAT3 (Tyr705) polyclonal IgG (catalog no. 9131; Cell Signaling Technology) at 1:1000 dilution $(1.0 \mu \mathrm{g} / \mathrm{ml})$, antihuman phospho-MAPK3/1 polyclonal IgG (catalog no. 9101; Cell Signaling Technology) at 1:2000 dilution $(0.5 \mu \mathrm{g} / \mathrm{ml})$, antirat STAT3 polyclonal IgG (catalog no. S21320; Transduction Laboratories Inc., Lexington, KY, USA) at 1:2500 dilution $(1.0 \mu \mathrm{g} / \mathrm{ml})$, and anti-human MAPK3/1 monoclonal IgG (catalog no. 4695; Cell Signaling Technology) at 1:5000 dilution. Multiple exposures of each western blot were performed to ensure linearity of chemiluminescent signals. Western blots were quantified using a ChemiDoc EQ system and Quantity One software (Bio-Rad).

\section{Statistical analyses}

All quantitative data were subjected to least-squares ANOVA using the Statistical Analysis System (SAS Institute, Cary, NC,
USA). Slot-blot hybridization data were corrected for differences in sample loading using the 18S rRNA data as a covariate. Data from ewes between days 10 and 16 (study 1) were analyzed for the effects of day, pregnancy status (cyclic or pregnant), and their interaction. Data from studies 2 and 3 were analyzed using orthogonal contrasts (day 9: CO versus P4, day 12: $\mathrm{CO}$ versus P4, and day 12: P4 versus P4+RU486 for study $2 ; \mathrm{P} 4+\mathrm{CX}$ versus $\mathrm{P} 4+\mathrm{IFN}, \mathrm{P} 4+\mathrm{ZK}+\mathrm{CX}$ versus $\mathrm{P} 4+$ $Z K+I F N, P 4+C X$ versus $P 4+Z K+C X$ for study 3$)$ to determine the effects of the treatment. All tests of significance were performed using the appropriate error terms according to the expectation of the mean squares for error. $P \leq 0.05$ was considered significant. Data are presented as least-squares means with (S.E.M).

\section{Declaration of interest}

The authors declare that there is no conflict of interest that could be perceived as prejudicing the impartiality of the research reported.

\section{Funding}

This research was funded in part by National Research Initiative Competitive Grant no. 2005-35203-16252 from the USDA Cooperative State Research, Education and Extension Service and National Institutes of Health Grant 5 R01 HD32534.

\section{References}

Auernhammer CJ \& Melmed S 2000 Leukemia-inhibitory factor-neuroimmune modulator of endocrine function. Endocrine Reviews 21 313-345.

Baulieu EE 1989 Contragestion and other clinical applications of RU 486, an antiprogesterone at the receptor. Science 245 1351-1357.

Bazer FW, Spencer TE \& Ott TL 1997 Interferon tau: a novel pregnancy recognition signal. American Journal of Reproductive Immunology 37 412-420.

Bhatt H, Brunet LJ \& Stewart CL 1991 Uterine expression of leukemia inhibitory factor coincides with the onset of blastocyst implantation. PNAS 88 11408-11412.

Chen C, Spencer TE \& Bazer FW 2000 Fibroblast growth factor-10: a stromal mediator of epithelial function in the ovine uterus. Biology of Reproduction 63 959-966.

Cheng JG, Chen JR, Hernandez L, Alvord WG \& Stewart CL 2001 Dual control of LIF expression and LIF receptor function regulate Stat3 activation at the onset of uterine receptivity and embryo implantation. PNAS 98 8680-8685.

Cheng JG, Rodriguez CI \& Stewart CL 2002 Control of uterine receptivity and embryo implantation by steroid hormone regulation of LIF production and LIF receptor activity: towards a molecular understanding of 'the window of implantation'. Reviews in Endocrine and Metabolic Disorders 3 119-126.

Daoud G, Amyot M, Rassart E, Masse A, Simoneau L \& Lafond J 2005 ERK $1 / 2$ and p38 regulate trophoblasts differentiation in human term placenta. Journal of Physiology 566 409-423.

Farmer JL, Burghardt RC, Jousan FD, Hansen PJ, Bazer FW \& Spencer TE 2008 Galectin 15 (LGALS15) functions in trophectoderm migration and attachment. FASEB Journal 22 548-560.

Fukui Y \& Matsuyama K 1994 Development of in vitro matured and fertilized bovine embryos cultured in media containing human leukemia inhibitory factor. Theriogenology $42663-673$.

Funston RN, Nauta WJ \& Seidel GE Jr 1997 Culture of bovine embryos in buffalo rat liver cell-conditioned media or with leukemia inhibitory factor. Journal of Animal Science 75 1332-1336. 
Gray CA, Taylor KM, Ramsey WS, Hill JR, Bazer FW, Bartol FF \& Spencer TE 2001 Endometrial glands are required for preimplantation conceptus elongation and survival. Biology of Reproduction 64 1608-1613.

Gray CA, Adelson DL, Bazer FW, Burghardt RC, Meeusen EN \& Spencer TE 2004 Discovery and characterization of an epithelial-specific galectin in the endometrium that forms crystals in the trophectoderm. PNAS 101 7982-7987.

Guillomot M 1995 Cellular interactions during implantation in domestic ruminants. Journal of Reproduction and Fertility Supplement 49 39-51.

Han YM, Lee ES, Mogoe T, Lee KK \& Fukui Y 1995 Effect of human leukemia inhibitory factor on in vitro development of IVF-derived bovine morulae and blastocysts. Theriogenology 44 507-516.

Van Heeke G, Ott TL, Strauss A, Ammaturo D \& Bazer FW 1996 High yield expression and secretion of the ovine pregnancy recognition hormone interferon-tau by Pichia pastoris. Journal of Interferon \& Cytokine Research 16 119-126.

Hoffman LH \& Wooding FB 1993 Giant and binucleate trophoblast cells of mammals. Journal of Experimental Zoology 266 559-577.

Ing NH \& Roberts RM 1989 The major progesterone-modulated proteins secreted into the sheep uterus are members of the serpin superfamily of serine protease inhibitors. Journal of Biological Chemistry 264 3372-3379.

Johnson GA, Burghardt RC, Newton GR, Bazer FW \& Spencer TE 1999a Development and characterization of immortalized ovine endometrial cell lines. Biology of Reproduction 61 1324-1330.

Johnson GA, Burghardt RC, Spencer TE, Newton GR, Ott TL \& Bazer FW $1999 b$ Ovine osteopontin: II. Osteopontin and alpha(v)beta(3) integrin expression in the uterus and conceptus during the periimplantation period. Biology of Reproduction 61 892-899.

Johnson GA, Spencer TE, Burghardt RC, Joyce MM \& Bazer FW 2000a Interferon-tau and progesterone regulate ubiquitin cross-reactive protein expression in the ovine uterus. Biology of Reproduction 62 622-627.

Johnson GA, Spencer TE, Burghardt RC, Taylor KM, Gray CA \& Bazer FW $2000 \mathrm{~b}$ Progesterone modulation of osteopontin gene expression in the ovine uterus. Biology of Reproduction 62 1315-1321.

Johnson GA, Burghardt RC, Bazer FW \& Spencer TE 2003 Osteopontin: roles in implantation and placentation. Biology of Reproduction 69 $1458-1471$.

Kim J, Song G, Gao H, Farmer JL, Satterfield MC, Burghardt RC, Wu G, Johnson GA, Spencer TE \& Bazer FW 2008 Insulin-like growth factor II activates phosphatidylinositol 3-kinase-protooncogenic protein kinase 1 and mitogen-activated protein kinase cell signaling pathways, and stimulates migration of ovine trophectoderm cells. Endocrinology 149 3085-3094.

Kimber SJ 2005 Leukaemia inhibitory factor in implantation and uterine biology. Reproduction 130 131-145.

Moffatt RJ, Bazer FW, Roberts RM \& Thatcher WW 1987 Secretory function of the ovine uterus: effects of gestation and steroid replacement therapy. Journal of Animal Science 65 1400-1410.

Mudgett JS, Ding J, Guh-Siesel L, Chartrain NA, Yang L, Gopal S \& Shen MM 2000 Essential role for p38alpha mitogen-activated protein kinase in placental angiogenesis. PNAS 97 10454-10459.

Poehlmann TG, Fitzgerald JS, Meissner A, Wengenmayer T, Schleussner E, Friedrich K \& Markert UR 2005 Trophoblast invasion: tuning through LIF, signalling via Stat3. Placenta 26 S37-S41.

Satterfield MC, Bazer FW \& Spencer TE 2006 Progesterone regulation of preimplantation conceptus growth and galectin 15 (LGALS15) in the ovine uterus. Biology of Reproduction 75 289-296.

Satterfield MC, Hayashi K, Song G, Black SG, Bazer FW \& Spencer TE 2008 Progesterone regulates FGF10, MET, IGFBP1, and IGFBP3 in the endometrium of the ovine uterus. Biology of Reproduction $\mathbf{7 9}$ $1226-1236$.

Shields DC, Harmon DL, Nunez F \& Whitehead AS 1995 The evolution of haematopoietic cytokine/receptor complexes. Cytokine 7 679-688.

Simmons DG \& Cross JC 2005 Determinants of trophoblast lineage and cell subtype specification in the mouse placenta. Developmental Biology 284 12-24.

Sirisathien S, Hernandez-Fonseca HJ, Bosch P, Hollet BR, Lott JD \& Brackett BG 2003 Effect of leukemia inhibitory factor on bovine embryos produced in vitro under chemically defined conditions. Theriogenology 59 1751-1763.
Song H \& Lim H 2006 Evidence for heterodimeric association of leukemia inhibitory factor (LIF) receptor and gp130 in the mouse uterus for LIF signaling during blastocyst implantation. Reproduction 131 341-349.

Song G, Spencer TE \& Bazer FW 2005 Cathepsins in the ovine uterus: regulation by pregnancy, progesterone, and interferon tau. Endocrinology 146 4825-4833.

Song G, Spencer TE \& Bazer FW 2006a Progesterone and interferon-tau regulate cystatin C in the endometrium. Endocrinology 147 3478-3483.

Song G, Bazer FW, Wagner GF \& Spencer TE 2006b Stanniocalcin (STC) in the endometrial glands of the ovine uterus: regulation by progesterone and placental hormones. Biology of Reproduction 74 913-922.

Song G, Bazer FW \& Spencer TE 2007 Pregnancy and interferon tau regulate RSAD2 and IFIH1 expression in the ovine uterus. Reproduction 133 285-295.

Song G, Kim J, Bazer FW \& Spencer TE 2008a Progesterone and interferon tau regulate hypoxia-inducible factors in the endometrium of the ovine uterus. Endocrinology 149 1926-1934.

Song G, Satterfield MC, Kim J, Bazer FW \& Spencer TE 2008b Gastrinreleasing peptide (GRP) in the ovine uterus: regulation by interferon tau and progesterone. Biology of Reproduction 79 376-386.

Spencer TE \& Bazer FW 2002 Biology of progesterone action during pregnancy recognition and maintenance of pregnancy. Frontiers in Bioscience 7 d1879-d1898.

Spencer TE \& Bazer FW 2004 Conceptus signals for establishment and maintenance of pregnancy. Reproductive Biology and Endocrinology 249.

Spencer TE, Becker WC, George P, Mirando MA, Ogle TF \& Bazer FW 1995 Ovine interferon-tau regulates expression of endometrial receptors for estrogen and oxytocin but not progesterone. Biology of Reproduction $\mathbf{5 3}$ 732-745.

Spencer TE, Ott TL \& Bazer FW 1996 tau-Interferon: pregnancy recognition signal in ruminants. Proceedings of the Society for Experimental Biology and Medicine 213 215-229.

Spencer TE, Bartol FF, Bazer FW, Johnson GA \& Joyce MM 1999a Identification and characterization of glycosylation-dependent cell adhesion molecule 1-like protein expression in the ovine uterus. Biology of Reproduction 60 241-250.

Spencer TE, Stagg AG, Ott TL, Johnson GA, Ramsey WS \& Bazer FW $1999 \mathrm{~b}$ Differential effects of intrauterine and subcutaneous administration of recombinant ovine interferon tau on the endometrium of cyclic ewes. Biology of Reproduction 61 464-470.

Spencer TE, Gray A, Johnson GA, Taylor KM, Gertler A, Gootwine E, Ott TL \& Bazer FW 1999c Effects of recombinant ovine interferon tau, placental lactogen, and growth hormone on the ovine uterus. Biology of Reproduction 61 1409-1418.

Spencer TE, Johnson GA, Bazer FW \& Burghardt RC 2004a Implantation mechanisms: insights from the sheep. Reproduction 128 657-668.

Spencer TE, Johnson GA, Burghardt RC \& Bazer FW 2004b Progesterone and placental hormone actions on the uterus: insights from domestic animals. Biology of Reproduction 71 2-10.

Spencer TE, Johnson GA, Bazer FW \& Burghardt RC 2007 Fetal-maternal interactions during the establishment of pregnancy in ruminants. Society of Reproduction and Fertility 64 379-396.

Spencer TE, Sandra O \& Wolf E 2008 Genes involved in conceptusendometrial interactions in ruminants: insights from reductionism and thoughts on holistic approaches. Reproduction 135 165-179.

Stewart CL, Kaspar P, Brunet LJ, Bhatt H, Gadi I, Kontgen F \& Abbondanzo SJ 1992 Blastocyst implantation depends on maternal expression of leukaemia inhibitory factor. Nature 359 76-79.

Stewart DM, Johnson GA, Vyhlidal CA, Burghardt RC, Safe SH, Yu-Lee LY, Bazer FW \& Spencer TE 2001 Interferon-tau activates multiple signal transducer and activator of transcription proteins and has complex effects on interferon-responsive gene transcription in ovine endometrial epithelial cells. Endocrinology 142 98-107.

Takahashi Y, Takahashi M, Carpino N, Jou ST, Chao JR, Tanaka S, Shigeyoshi Y, Parganas E \& Ihle JN 2008 Leukemia inhibitory factor regulates trophoblast giant cell differentiation via Janus kinase 1-signal transducer and activator of transcription 3-suppressor of cytokine signaling 3 pathway. Molecular Endocrinology 22 1673-1681.

Taylor KM, Chen C, Gray CA, Bazer FW \& Spencer TE 2001 Expression of messenger ribonucleic acids for fibroblast growth factors 7 and 10 , 
hepatocyte growth factor, and insulin-like growth factors and their receptors in the neonatal ovine uterus. Biology of Reproduction $\mathbf{6 4}$ $1236-1246$.

Vogiagis D \& Salamonsen LA 1999 Review: the role of leukaemia inhibitory factor in the establishment of pregnancy. Journal of Endocrinology $\mathbf{1 6 0}$ 181-190.

Vogiagis D, Fry RC, Sandeman RM \& Salamonsen LA 1997a Leukaemia inhibitory factor in endometrium during the oestrous cycle, early pregnancy and in ovariectomized steroid-treated ewes. Journal of Reproduction and Fertility 109 279-288.

Vogiagis D, Salamonsen LA, Sandeman RM, Squires TJ, Butt AR \& Fry RC $1997 b$ Effect of immunisation against leukaemia inhibitory factor on the establishment of pregnancy in sheep. Reproduction, Nutrition, Development 37 459-468.

Wang Y, Wang F, Sun T, Trostinskaia A, Wygle D, Puscheck E \& Rappolee DA 2004 Entire mitogen activated protein kinase (MAPK) pathway is present in preimplantation mouse embryos. Developmental Dynamics 231 72-87.

Ware CB, Horowitz MC, Renshaw BR, Hunt JS, Liggitt D, Koblar SA, Gliniak BC, McKenna HJ, Papayannopoulou T, Thoma B et al. 1995
Targeted disruption of the low-affinity leukemia inhibitory factor receptor gene causes placental, skeletal, neural and metabolic defects and results in perinatal death. Development 121 1283-1299.

Wathes DC \& Hamon M 1993 Localization of oestradiol, progesterone and oxytocin receptors in the uterus during the oestrous cycle and early pregnancy of the ewe. Journal of Endocrinology 138 479-492.

Wooding FB 1992 Current topic: the synepitheliochorial placenta of ruminants: binucleate cell fusions and hormone production. Placenta 13 101-113.

Yoshida K, Taga T, Saito M, Suematsu S, Kumanogoh A, Tanaka T, Fujiwara H, Hirata M, Yamagami T, Nakahata T et al. 1996 Targeted disruption of gp130, a common signal transducer for the interleukin 6 family of cytokines, leads to myocardial and hematological disorders. PNAS 93 407-411.

Received 16 October 2008

First decision 12 November 2008

Accepted 4 December 2008 